\title{
The Quality of Life on Asthmatic Adolescent and Its Correlation with the Severity and Control of Asthma
}

\author{
Lisa Adhia Garina, ${ }^{1}$ Muhammad Ridho Grahadinta, ${ }^{2}$ \\ Ferry Achmad Firdaus Mansoer, ${ }^{3}$ Intan Puspitasari ${ }^{2}$ \\ ${ }^{1}$ Department of Pediatric, Faculty of Medicine, Universitas Islam Bandung, Jakarta, Indonesia, \\ ${ }^{2}$ Medical Undergraduate Study Program, Faculty of Medicine, Universitas Islam Bandung, Bandung, Indonesia, \\ ${ }^{3}$ Department of Obstetrics and Gynecology, West Java Provincial Al-Ihsan Regional General Hospital, \\ Bandung, Indonesia
}

\begin{abstract}
Asthma is considered a global health problem that, if not managed properly, can reduce the sufferers' quality of life. The purpose of the study was to evaluate the quality of life from the perspectives of asthma severity and the asthma control level. A cross-sectional study was conducted from February to June 2018 on asthmatic adolescents aged 12-14 years old in two public junior high schools in Bandung city, Indonesia. The diagnosis, history of asthma, severity, and asthma control were established based on the National Asthma Guidelines from the Indonesian Pediatric Society, Global Initiative for Asthma (GINA), asthma control test (ACT), and ISAAC questionnaire. Statistical analysis performed using SPSS v.20 with Spearman's rho to determine the significance. The gender distribution of the 98 subjects was almost similar with slightly more girls (51\%). The median age was $13 \pm 1$ years with average ACT, FVC, and PAQLQ(S) total scores of $20 \pm 4,78 \pm 16 \%$, and $5 \cdot 3 \pm 1.3$, respectively. The domain scores for symptoms, activity limitations, and emotional function were 4.9 $\pm 1.4,5.0 \pm 1.3$, and 5.7 \pm 1.1 , respectively. There are correlations between the total PAQLQ(S) score and asthma severity $(\mathrm{p}<0.001, \mathrm{r}=-0.5)$ and the level of asthma control ( $\mathrm{p}<0.001, \mathrm{r}=0.6$ ). In summary, the quality of life has a relationship with asthma severity and the level of asthma control. Asthma management should not only focus on medication but also ways to maintain a good quality of life.
\end{abstract}

Key words: Adolescents, asthma, PAQLQ(S), quality of life

\section{Kualitas Hidup Remaja Asma dan Hubungannya dengan Kekerapan Gejala dan Derajat Kendali Asma}

\begin{abstract}
Abstrak
Asma masih menjadi masalah kesehatan penting yang jika tidak ditangani baik, asma dapat menurunkan kualitas hidup anak. Tujuan penelitian ini menilai kualitas hidup dan hubungannya dengan kekerapan gejala dan derajat kendali asma. Penelitian cross-sectional ini dilaksanakan dari bulan Februari hingga Juni 2018 pada remaja asma berusia 12-14 tahun di dua SMPN di Kota Bandung, Indonesia. Diagnosis, riwayat asma, kekerapan gejala, dan derajat kendali asma berdasar atas Pedoman Nasional Asma Anak Ikatan Dokter Anak Indonesia, Global Initiative for Asthma (GINA), asthma control test (ACT), dan kuesioner dari ISAAC. Analisis statistik menggunakan SPSS v.20 dengan uji Spearman's rho untuk menentukan signifikansi. Distribusi gender dari 98 subjek penelitian hampir sama dengan sedikit lebih banyak perempuan (51\%). Usia rerata subjek $13 \pm 1$ tahun dengan skor rerata ACT, FVC, PAQLQ(S) masing-masing $20 \pm 4,78 \pm 16 \%$, dan 5,3 $\pm 1,3$. Skor domain gejala, keterbatasan beraktivitas,

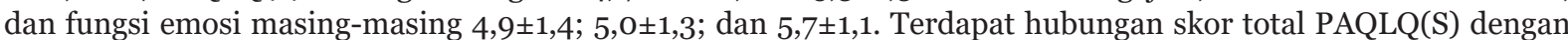
kekerapan gejala $(\mathrm{p}<0,001 ; \mathrm{r}=-0,5)$ dan dengan derajat kendali asma $(\mathrm{p}<0,001 ; \mathrm{r}=0,6)$. Simpulan, kualitas hidup berhubungan dengan kekerapan gejala dan derajat kendali asma. Pengelolaan asma sebaiknya tidak hanya memperhatikan pengobatan, tetapi juga menjaga kualitas hidup yang baik.
\end{abstract}

Kata kunci: Asma, kualitas hidup, PAQLQ(S), remaja

Received: 1 April 2020; Revised: 11 April 2020; Accepted: 14 April 2020; Published: 30 April 2020

Correspondence: Lisa Adhia Garina, dr., M.Si.Med., Sp.A. Department of Pediatric, Faculty of Medicine, Universitas Islam Bandung. Jln. Tamansari No. 22, Bandung 40116, West Java, Indonesia. E-mail: lisa.adhia@gmail.com 


\section{Introduction}

Asthma is a disease caused by chronic inflammation of the respiratory tract that has various symptoms and is characterized by a history of wheezing, chest tightness, and time and intensity-based coughing accompanied by limited expiratory airflow. ${ }^{1}$ Asthma symptoms are chronic or recurrent and reversible. They are also more severe at night or in early mornings, usually arose when there is a trigger. ${ }^{2}$

The prevalence of asthma is $1-18 \%$ of the population in many countries. ${ }^{1}$ In Indonesia, the prevalence of asthma among adolescents aged $13-14$ years old is 2.6 to $24.4 \% .^{2}$ A previous study stated that the prevalence of asthma among adolescents aged 13-14 years old in Jakarta is $12.2 \% .^{3}$ The global community has agreed on the target to decrease the prevalence of asthma by $2025 ; 4$ however, in the last two decades, the prevalence of asthma has continued to increase, especially in developing countries. ${ }^{2,5}$ Globally, asthma is ranked $16^{\text {th }}$ among the leading causes of years lived with disability and $28^{\text {th }}$ among the leading causes of the burden of disease. ${ }^{6}$

The reason why asthma is still a global common heath problem is that it has not been managed properly; therefore, it reduces the quality of children's life, restricts their daily activities, disturbs sleeping, increases the rate of absenteeism of school, and decrease academic achievement. If asthma is not well-controlled, it can increase health costs. ${ }^{2}$ Childhood asthma is linked to many physical health and psychosocial health conditions, which may cause significant decreases in the health-related quality of life of the children and their caregivers. ${ }^{7}$

Quality of life assessment is a multidimensional assessment as it does not only assess the effect of treatment on the physical or psychological aspects of the patients but also describes the health condition of the patients and families during or after treatment. ${ }^{8}$ Thus, the determination of the quality of life of these patients can make the treatment decision making easier hence new solutions can be offered to the treatment team. ${ }^{9}$

A previous study suggested that the rate of impaired quality of life in asthma is relatively high $(26.8-35 \%)$ with the degree of partly controlled and uncontrolled asthma variable becomes the risk factor for the low quality of life. ${ }^{8}$ Children and adolescents with controlled asthma with intermittent asthma attacks and a history of low drug use have a better quality of life..$^{10,11}$ Controlled and partly controlled asthma children presented a total value of Pediatric Asthma Quality of Life Questionnaire (PAQLQ) that is higher than those with uncontrolled asthma ( $\mathrm{p}<\mathrm{0.001)}$. The group with mild asthma also had a higher total PAQLQ value, symptom domain, and emotional function domain compared to the moderate and severe asthma groups $(\mathrm{p}<0.001) .^{10}$

The purpose of this study was to evaluate the quality of life of asthmatic adolescents and the correlation between the quality of life and the severity and level of asthma control.

\section{Methods}

A cross-sectional observational study on 98 adolescents with asthma aged 12-14 years old in two junior high schools in Bandung was conducted from February to June 2018. The inclusion criteria for this study were male and female adolescents with asthma aged 12-14 years old and parents or caregivers of asthmatic children who were willing to participate in this study. Participants were excluded if they had an acute attack or exacerbation of asthma, fever, coughing, and runny nose during the study. Those who could not do spirometry examination and had cognitive and motoric limitations were also excluded.

Asthma diagnosis and history were made based on the Global Initiative for Asthma (GINA), National Asthma Guidelines Indonesian Pediatric Society (Pedoman Nasional Asma Anak Ikatan Dokter Anak Indonesia/PNAA-IDAI), and questionnaires from the International Study of Asthma and Allergies in Childhood (ISAAC). The criteria for asthma severity were made based on the PNAA-IDAI with the following categories: intermittent (episodes of asthma symptoms $<6$ times per year or distance between symptoms $\geq 6$ weeks), mild persistence (episodes of asthma symptoms $>1$ time per month, <1 time per week), moderate persistence (episodes of asthma symptoms $>1$ time per week, but not every day), and severe persistence (episodes of asthma symptoms occur almost every day). The degree of asthma control is categorized based on the PNAA-IDAI and asthma control test (ACT) for 12 years old into uncontrolled, partly controlled, and controlled with or without drugs. Asthma was considered to be controlled if the score was 25. A score of between 20-24 represented asthma that was partly controlled while a score of $<19$ indicated that the asthma was uncontrolled. 
The quality of life was assessed based on the Pediatric Asthma Quality of Life Questionnaire (Standardized) (PAQLQ(S)) that consists of 23 questions in three domains, namely symptoms, activity, and emotional function. A scale of 1 to 7 was used, with 1 indicated severe interference, and 7 indicated no interference. The quality of life of adolescents with asthma was classified into the following categories: minimum or no impairment (score $\geq 6.0$ ), moderate impairment (score 3.05.9), and severe impairment (score <3.0).

Examination of pulmonary function using spirometry conducted to determine the force expiratory volume 1 minute (FEV1) and force vital capacity (FVC) values as well as the FEV1/ FVC ratio. Data were analyzed using SPSS v.20 software, and the significance of variables was identified using the Spearman 's rho test.

This study had approved by the Health Research Ethics Committee of the Faculty of Medicine, Universitas Islam Bandung, Indonesia, through the issuance of the ethical clearance number: 313/Komite Etik.FK/III/2018.

\section{Results}

There were 105 students identified with asthma from a total of 2,579 students (4.1\%). By applying the inclusion and exclusion criteria using the consecutive sampling approach, 98 research subjects were obtained.

The number of female subjects (51\%) was slightly higher than the male subjects while the mean age of these subjects was $13 \pm 1$ years. The average ACT score was $20 \pm 4$ and the FVC value was $78 \pm 16 \%$. The total score for PAQLQ(S) was $5.3 \pm 1.3$ while the PAQLQ(S) scores for the symptom domain, activity limitation domain, and emotional function domain were $4.9 \pm 1.4$, $5.0 \pm 1.3$, and $5 \cdot 7 \pm 1.1$, respectively.

The characteristics of the study subjects based on the asthma severity, asthma control level, and quality of life are listed in Table 1.

Based on Table 1, most subjects had intermittent asthma (43\%), partly controlled asthma (55 people), and moderate impairment.

The correlation between the components of quality of life and asthma severity as well as between quality of life and asthma control level can be seen in Table 2 and Table 3. The total PAQLQ(S) score and the PAQLQ(S) scores for all domains in severe persistent asthma group were lower than those in other severity levels of asthma. In severe persistent asthma, the quality was severely impaired (2.9 \pm 0.6$)$, as described in Table 2.

There was a correlation between the total quality of life score (PAQLQ(S)) and the asthma severity $(\mathrm{p}<0.001, \quad \mathrm{r}=-0.5)$. Subjects with intermittent asthma had a higher total PAQLQ(S) score and overall domain scores. The less the frequency of symptoms is the higher the total PAQLQ score.

Table 3 shows that the mean total PAQLQ(S) score in the uncontrolled asthma group was lower (4.6[0.9]) than in the controlled asthma group (5.9[2.4]). There was a strong correlation between the total score of the quality of life (PAQLQ(S)) and the asthma control level $(\mathrm{p}<0.001, \mathrm{r}=0.6)$. Subjects with uncontrolled asthma had a lower total PAQLQ(S) score and overall domain score.

\section{Discussion}

The results of this study revealed that the majority of subjects experienced intermittent asthma. A study by Banasiak ${ }^{12}$ also found that most subjects had intermittent asthma in primary care. A previous study identified that children treated by asthma specialists were more likely to have severe persistent asthma and poorly controlled asthma compared with those seen by primary care physicians..$^{13}$ This study was conducted in the community so the results will be different if the study was done in a tertiary referral hospital

Table 1 Distribution of Asthma Severity, Asthma Control Level, and Quality of Life

\begin{tabular}{lc}
\hline Variables & $\mathbf{n = 9 8}(\%)$ \\
\hline Asthma severity & \\
Intermittent & $42(43)$ \\
Mild persistence & $35(36)$ \\
Moderate persistence & $17(17)$ \\
$\quad$ Severe persistence & $4(4)$ \\
Asthma control & \\
$\quad$ Controlled & $37(38)$ \\
$\quad$ Partly controlled & $55(56)$ \\
$\quad$ Uncontrolled & $6(6)$ \\
Quality of life (PAQLQ(S)) & \\
$\quad$ Without and minimal & $34(35)$ \\
$\quad$ impairment & \\
$\quad$ Moderate impairment & $61(62)$ \\
Severe impairment & $3(3)$ \\
\hline $\begin{array}{l}\text { Note: "PAQLQ(S)= Pediatric Asthma Quality of Life } \\
\text { Questionnaire (Standardized) }\end{array}$ &
\end{tabular}


Table 2 Correlation between Quality of Life Domain (PAQLQ(S)) Score and Asthma Severity

\begin{tabular}{|c|c|c|c|c|c|c|}
\hline \multirow[b]{2}{*}{ PAQLQ(S) Score } & \multicolumn{4}{|c|}{ Asthma Severity } & \multirow[b]{2}{*}{$\mathbf{r}$} & \multirow[b]{2}{*}{$\mathbf{p}^{*}$} \\
\hline & Intermittent & $\begin{array}{c}\text { Mild } \\
\text { Persistence }\end{array}$ & $\begin{array}{l}\text { Moderate } \\
\text { Persistence }\end{array}$ & $\begin{array}{c}\text { Severe } \\
\text { Persistence }\end{array}$ & & \\
\hline $\begin{array}{l}\text { Total } \\
\quad \text { Mean }(\mathrm{SD})^{* * *}\end{array}$ & $5.8(1.4)$ & $5.1(0.9)$ & $4.9(0.9)$ & $3.9(0.3)$ & -0.5 & $<0.001$ \\
\hline $\begin{array}{l}\text { Symptoms } \\
\text { Mean (SD) }\end{array}$ & $5.5(1.3)$ & $4.6(1.2)$ & $4.5(1.2)$ & $2.9(0.6)$ & -0.4 & 0.001 \\
\hline $\begin{array}{l}\text { Activity limitations } \\
\text { Mean (SD) }\end{array}$ & $5.6(1.3)$ & $4.7(1.1)$ & $4.6(1.1)$ & $3.3(0.9)$ & -0.4 & 0.001 \\
\hline $\begin{array}{l}\text { Emotional function } \\
\text { Mean (SD) }\end{array}$ & $6.1(1.1)$ & $5.4(0.9)$ & $5.3(0.7)$ & $4.1(0.5)$ & -0.5 & $<0.001$ \\
\hline
\end{tabular}

Note: *Spearman's rho; **SD: standard deviation; significantly statistic $(\mathrm{p}<0.05)$

where asthma cases with different severity are seen.

This study indicated that the majority of the study subjects with partly controlled and intermittent asthma. Silva et al. ${ }^{14}$ also found that the majority of subjects in his study had partly controlled asthma. A previous study stated that most of its subjects had controlled asthma and other studies found that the majority of subjects experienced mild asthma. ${ }^{15,16}$ Banjari et al. ${ }^{17}$ found that most subjects in their study experienced uncontrolled asthma, while a different study found that the majority of patients with asthma were uncontrolled before being given inhaler therapy for six weeks. ${ }^{18}$ Another study also found that only $12 \%$ of the subjects had controlled asthma. ${ }^{19}$ The percentage of asthma control level varies in different countries, which might depend on the method used, the sample size, and the assessment tools used in the respective country. One study has shown that the subjects of the study, recruited from the pulmonology clinic, experienced severe and uncontrolled asthma. This will certainly be different if the subjects were recruited from general practitioner clinics, general pediatricians, and family doctors as they may only have mild asthma (controlled asthma). ${ }^{17}$

The findings of the current study suggested that the quality of life is related to asthma severity and asthma control level in adolescents. Intermittent and controlled asthma presents a higher total PAQLQ(S) score compared to severe and uncontrolled persistent asthma. Matsunaga et al. ${ }^{10}$ also stated that the quality of life is directly related to controlled asthma and severity of asthma in children and adolescents, which is better in controlled asthma and mild asthma. In controlled and partly controlled asthma,

Table 3 Correlation between the Quality of Life Domain Score (PAQLS(S)) and Asthma Control Level

\begin{tabular}{|c|c|c|c|c|c|}
\hline \multirow[b]{2}{*}{ PAQLQ(S) Score } & \multicolumn{3}{|c|}{ Asthma Control Level } & \multirow[b]{2}{*}{$\mathbf{r}$} & \multirow[b]{2}{*}{$\mathbf{p}^{*}$} \\
\hline & Controlled & $\begin{array}{c}\text { Partly } \\
\text { Controlled }\end{array}$ & Uncontrolled & & \\
\hline $\begin{array}{l}\text { Total } \\
\quad \text { Mean (SD) }\end{array}$ & $5.9(2.4)$ & $5.7(1.1)$ & $4.6(0.9)$ & 0.6 & $<0.001$ \\
\hline $\begin{array}{l}\text { Symptoms } \\
\text { Mean (SD) }\end{array}$ & $5.8(2.4)$ & $5.5(1.0)$ & $4.1(1.2)$ & 0.6 & $<0.001$ \\
\hline $\begin{array}{l}\text { Activity limitations } \\
\text { Mean (SD) }\end{array}$ & $5.8(2.4)$ & $5.4(1.0)$ & $4.3(1.1)$ & 0.5 & $<0.001$ \\
\hline $\begin{array}{l}\text { Emotional function } \\
\text { Mean (SD) }\end{array}$ & $5.8(2.4)$ & $6.0(0.8)$ & $5.0(0.9)$ & 0.5 & $<0.001$ \\
\hline
\end{tabular}

Note: *Spearman's rho; **SD: standard deviation; significantly statistic $(\mathrm{p}<0.05)$ 
the PAQLQ(S) and overall domain scores were higher than uncontrolled asthma $(\mathrm{p}<0.001) .^{10}$ Uncontrolled asthma that is identified through frequent waking up at night, frequent wheezes, visits to the emergency rooms (ER), or hospital admission is associated with poor quality of life of both asthmatic children and their caregivers. ${ }^{20}$

Previous studies also found that groups with controlled asthma had higher PAQLQ scores. ${ }^{21,22}$ El-Gilany et al. ${ }^{23}$ also found that patients with controlled asthma have significantly better total score and domain scores from the three domains. Also, patients with severe asthma have significantly worse total and categorical PAQLQ scores. $^{23}$

There is a strong correlation between the PAQLQ score and the asthma control test (ACT) score in moderate to severe asthma. ${ }^{18}$ Several previous studies also indicate a strong correlation between ACT and PAQLQ, 24,25 that the degree of controlled asthma can affect the total score of quality of life for parents, children, and adolescents with asthma. ${ }^{26}$ Management of asthma should not only be seen as a medical treatment. It should also include psychological supports and counseling to maintain the quality of life. ${ }^{27}$

This study has a limitation in not examining other factors related to the quality of life of asthmatics adolescents.

\section{Conclusion}

Quality of life is correlated with asthma severity and asthma control level in adolescents.

\section{Conflict of Interest}

Authors declare no conflict of interest in this article.

\section{Acknowledgments}

Faculty of Medicine of Universitas Islam Bandung, 1 and 9 Junior High Schools Bandung city, Bandung Education Office, and Bandung City Health Office.

\section{References}

1. Global Initiative for Asthma (GINA). Global strategy for asthma management and prevention. 2020 Update [Internet]. Bethesda: GINA; 2020 [cited 2020 April 14].
Available from: https://ginasthma.org/wpcontent/uploads/2020/04/GINA-2020-fullreport_-final-_wms.pdf.

2. Rahajoe N, Kartasasmita CB, Supriyatno B, Setyanto DB. Pedoman nasional asma anak. $2^{\text {nd }}$ Edition. $2^{\text {nd }}$ Printing. Jakarta: Ikatan Dokter Anak Indonesia; 2016.

3. Yunus F, Rasmin M, Sutoyo DK, Wiyono WH, Antariksa B, Fitriani F, et al. Prevalens asma pada siswa usia 13-14 tahun berdasarkan kuesioner ISAAC di Jakarta. J Respir Indo. 2011;31(4):176-80.

4. Global Asthma Network. The global asthma report 2014. Auckland, New Zealand: Global Asthma Network: 2014 [cited 2020 January 13]. Available from: http://www. globalasthmanetwork.org/publications/ Global_Asthma_Report_2014.pdf.

5. Global Initiative for Asthma (GINA). Pocket guide for asthma management and prevention for adults and children older than 5 years: a pocket guide for health professionals. Update 2020. Bethesda: GINA; 2020 [cited 2020 April 13]. Available from: https://ginasthma. org/wp-content/uploads/2020/o4/Mainpocket-guide_2020_04_03-final-wms.pdf.

6. Global Asthma Network. The global asthma report 2018. Auckland, New Zealand: Global Asthma Network: 2018 [cited 2020 April 14]. Available from: http:// www.globalasthmareport.org/Global\%20 Asthma\%20Report\%202018.pdf.

7. Qu CX, Zhang ZK. Current views of pediatric asthma. Eur Rev Med Pharmacol Sci. 2017;21(4 Suppl):106-8.

8. Wigoeno Y, Sekartini R, Setyanto DB, Hadinegoro SRS. Assessing the quality of life of asthmatic children using the PedQL ${ }^{\mathrm{TM}}$. Paediatr Indones. 2011;51(5):245-51.

9. Kouzegaran S, Samimi P, Ahanchian H, Khoshkhui M, Behmanesh F. Quality of life in children with asthma versus healthy children. Open Access Maced J Med Sci. 2018;6(8):1413-8.

10. Matsunaga NY, Ribeiro MAGDO, Saad IAB, Morcillo AM, Ribiero JD, Toro AADC. Evaluation of quality of life according to asthma control and asthma severity in children and adolescents. J Bras Pneumol. 2015;41(6);502-8.

11. Miadich SA, Everhart RS, Borschuk AP, Winter MA, Fiese BH. Quality oflife in children with asthma: a developmental perspective. J Pediatr Psycol. 2015;40(7):672-9. 
12. Banasiak NC. Implementation of the asthma control test in primary care to improve patient outcomes. J Pediatr Health Care. 2018;32(6):591-9.

13. Nyenhuis SM, Akkoyun E, Liu L, Schatz M, Casale TB. Real-world assessment of asthma control and severity in children, adolescents, and adults with asthma: relationships to care settings and comorbidities. J Allergy Clin Immunol Pract. 2020;8(3):989-96.

14. Silva AAMD, Maciel ÁCC, Furtado PR, Tomaz RR, Macêdo TMF, Mendonça KMPP. Applicability of a generic questionnaire for quality of life assessment for asthmatic children. Rev Paul Pediatr. 2018;36(2):20713.

15. Halwani R, Al-kufeidy R, Muharib BA, Alkhashram FM, Hussain SIB, Alhenaki RS, et al. Impact of asthma on the quality of life of adolescent patients from Saudi Arabia. J Lung Dis Treatment. 2016;2(3):1000114.

16. BinSaeed AA, Torchyan AA, Alsadhan AA, Almidani GM, Alsubaie AA, Aldakhail AA, et al. Determinants of asthma control among children in Saudi Arabia. J Asthma. 2014;51(4):435-9.

17. Banjari M, Kano Y, Almadani S, Basakran A, Al-Hindi M, Alahmadi T. The relation between asthma control and quality of life in children. Int J Pediatr. 2018;2018:6517329.

18. Karadeniz P, Özdoğan Ş, Ayyıldız-Emecen D, Öncül Ü. Asthma control test and pediatric asthma quality of life questionnaire association in children with poor asthma control. Turk J Pediatr. 2016;58(5):464-72.

19. Al Zahrani SS, El Morsy EMA, Dorgham LS. The impact of bronchial asthma on quality of life among affected children and adolescents in Taif city, Saudi Arabia. Life Sci J. 2014;11(6):283-91.

20. Ibrahim NK, Alhainiah M, Khayat M,
Abulaban O, Almaghrabi S, Felmban O. Quality of life of asthmatic children and their caregivers. Pak J Med Sci. 2019;35(2):521-6.

21. Al-Gewely MS, El-Hosseiny M, Abou Elezz NF, El-Ghoneimy DH, Hassan AM. Healthrelated quality of life in childhood bronchial asthma. Egypt J Pediatr Allergy Immunol. 2013;11(2):83-93.

22. Voorend-van Bergen S, Vaessen-Verberne AA, Landstra AM, Brackel HJ, van den Berg NJ, Caudri D, et al. Monitoring childhood asthma: web-based diaries and the asthma control test. J Allergy Clin Immunol. 2014;133(6):1599-605.

23. El-Gilany AH, El Desoky T, El-Hawary AK, Farrag M. Quality of life of children with bronchial asthma and their caregivers: a hospital-based study. Prog Med Sci. 2018;2(1):1-8.

24. Nordlund B, Konradsen JR, Pedroletti C, Kull I, Hedlin G. The clinical benefit of evaluating health-related quality-of-life in children with problematic severe asthma. Acta Paediatr. 2011;100(11):1454-60.

25. Amaral LM, Moratelli L, Palma PV, Leite IC. The quality of life of Brazilian adolescents with asthma: associated clinical and sociodemographic factors. J Asthma. 2014;51(6):660-6.

26. Costa DD, Pitrez PM, Barroso NF, Roncada C. Asthma control in the quality of life levels of asthmatic patients' caregivers: a systematic review with meta-analysis and meta-regression. J Pediatr (Rio J). 2019;95(4):401-9.

27. Nair S, Nair S, Sundaram KR. A prospective study to assess the quality of life in children with asthma using the pediatric asthma quality of life questionnaire. Indian J Allergy Asthma Immunol. 2014;28(1):13-8. 